\title{
Alexander Fantalkin, Oren Tal. Re-discovering the Iron Age fortress at Tell Qudadi in the context of Neo- Assyrian imperialistic policies
}

\section{Astrid Nunn}

\section{(2) OpenEdition \\ 1 Journals}

Édition électronique

URL : http://journals.openedition.org/abstractairanica/40258

DOI : 10.4000/abstractairanica.40258

ISSN : 1961-960X

Éditeur :

CNRS (UMR 7528 Mondes iraniens et indiens), Éditions de l'IFRI

Édition imprimée

Date de publication : 1 décembre 2013

ISSN : 0240-8910

Référence électronique

Astrid Nunn, «Alexander Fantalkin, Oren Tal. Re-discovering the Iron Age fortress at Tell Qudadi in the context of Neo-Assyrian imperialistic policies », Abstracta Iranica [En ligne], Volume 32-33 | 2013, document 66, mis en ligne le 01 juillet 2016, consulté le 26 septembre 2020. URL : http:// journals.openedition.org/abstractairanica/40258; DOI : https://doi.org/10.4000/abstractairanica 40258

Ce document a été généré automatiquement le 26 septembre 2020.

Tous droits réservés 


\title{
Alexander Fantalkin, Oren Tal. Re- discovering the Iron Age fortress at Tell Qudadi in the context of Neo-Assyrian imperialistic policies
}

\author{
Astrid Nunn
}

\section{RÉFÉRENCE}

Alexander Fantalkin, Oren Tal. « Re-discovering the Iron Age fortress at Tell Qudadi in the context of Neo-Assyrian imperialistic policies ». PEQ 141/3, 2009, p. 188-206.

1 Le site de Tell Qudadi, situé dans le Tel Aviv moderne sur la rive méditerranéenne au nord de l'embouchure du Yarkon, a déjà été fouillé en 1937 et 1938. S'y trouve un fort imposant construit à l'époque néo-assyrienne, seule époque qui intéresse les auteurs. Néanmoins, certains murs à appareillage à piliers sont achéménides (Stratum II).

\section{AUTEURS}

ASTRID NUNN

Université de Munich 